\title{
Economic growth and unemployment rate. Case of Albania
}

\author{
Emirgena Nikolli \\ emirgenanikolli@hotmail.com
}

\begin{abstract}
This thesis studies the relationship between the economic growth and the unemployment rate in Albania. This relation is known as Okun's law, which states that 1 percent decrease in unemployment; GDP will increase by 3 percent. Albania is one of the countries that have a sluggish development and impact of unemployment is negative in the economy of the country. At the same time the economy itself effect the employment of the people. The unemployment occurs when people are without work or seeking work. During recession there is a high unemployment rate. Even some peaks of the development like in the Total Factor Productivity, integration or infrastructure there have been recession and a bad time for the Albania too. This affected the investments, the business and by lowering their profits they are obligated to lay off employees. So the unemployment rate starts to rise up. This study takes in consideration the years from 2000 to 2013 when the unemployment was rising day by day with negative impact in the economy. This thesis introduces the general relationship between gross domestic product and unemployment. The methodology used a simple regression and takes the economic growth as dependent variable and the unemployment rate as independent. The observed result didn't explain the Okun's law for Albania. The main reason is the current crises that prevent the improvement of economic conditions.
\end{abstract}

Keywords: Economic Growth, Unemployment Rate, Albanian Economy.

\section{Introduction}

This thesis introduces unemployment and economic growth of the Albania. Unemployment is strongly related with the GDP of the country. The objective of this thesis is to find the relation between them and the impact that they have to each other. Unemployment is nowadays a main problem occurring in Albania. People that are not working or seeking for work so jobless form the concept of unemployment. Unemployment rate is measured by the number of unemployed people over the all population. Actually in Albania the unemployment is 13.5 percent which is relatively high but decreased related with the 2013 year when unemployment rate was 16.9 percent. Still this rate for the females is higher than males but the number of employed females is increasing day by day in Albania. Youth unemployment continues to be spread phenomena in the society since after finishing the studies it is difficult to find a job and this lead to the joblessness for the graduated ones this number is 27,2 percent for people 15 till 24 years old. Unemployment is categorized in the structural unemployment that means labor markets does not need some workers with specific skills also the frictional unemployment when the worker is searching for a job. There exists hidden unemployment too that means is not reflected in the unemployment statistics, the cyclical unemployment that happens when the economy cannot provide jobs or the classical unemployment that usually happens because of the low wages. To find a relation let's tell about the economy of Albania which according to some statistics like those of IMF the country even though of crises economy grew by 22 percent from 2007 to 2012. The Euro zone bad situation in 2012 effected the GDP of the Albania and it declined so remaining weak for the year 2013 also. What effects the economic growth is at the same time the labor force of the Albania, GDP growth rate was averaged 1 percent, this rate is result of some factors but unemployment has its impact as well. Labor force is important for the output since they are a main factor in the business. In Albania the sector that is increasing the GDP is still agriculture but the industry is increasing faster also. The agriculture has more employed people than industry that's why the effect of them is higher in the GDP. After the transition and after the period of recession the unemployment fall because when there is bad time for the economy the business lay off the workers since they are producing less. So the relation between the economic growth and unemployment is interdependent that explains how the economy changes when there is a high number of unemployed people and how this phenomena effect negatively in the economy as well. When there is a growth in the real gross domestic product which exceeds growth of the labor productivity then employment will rise and if this is rapid there is labor force growth than unemployment will decline. After the transition the agriculture had the higher number of employees even this sector had the lowest productivity and the services sector with the highest productivity had 60 percent of people employed. According to (Kota, 2007)the labor productivity it is important for the economic growth, and in order to be efficient labor force has to shift from less productive sectors to more productive ones. To remain still to the unemployment, one of the factors that are increasing it not only in Albania is the technology which is substituting the skills of the workers and this leads to the less number of people working. Anyway there are a lot of reason that have direct impact in the economy where 
the political reasons can be included also but according to business cycle is going to come a increase for the economy so the business will be able to produce more so to high more people and the economic growth will happens since there can be more exports and less imports. Despite its growth Albania still is one of the countries with the lowest wages but this cheap labor costs affect the economy negatively since people are not satisfied and do not have tendency to work. Economic growth is main goal of every country economic, monetary and fiscal policy. The investments are important in helping the economy and choosing the unemployment problem. So economic policies tends to increase the economic growth that lead to reduce of unemployment and the investment policies are creating more jobs by their investment programs. Unemployment is a global phenomenon that has economic and social effect and every country despite the development is facing with it. This study identifies the correlation of this phenomenon and the economic growth for the Albania, despite the theoretical part that shows the negative relation this research is based in the methodology which uses as unemployment rate as dependent and economic growth as independent variable and again proving not a positive relation between them. This study is based in specific years and takes the sources from the INSTAT, World Bank and IMF, it is important because identifies the relationship between unemployment and the economic growth and underlines this relationship. It takes real facts of the economy of Albania and related with the Okun's law and the regression analysis done this relationship will be showed in the papers of this research.

\section{Literature Review}

There have been many theoretical debates about the effect of the unemployment rate in the economic growth. Arthur Okun a professor and economist proposed a relationship between them in 1962 and called it Okun's law that states 1 percent decrease in unemployment the GDP will increase by 3 percent. But this economist says that this relationship varies from the country and the time. This is an empirical study that proves the imperfect relationship between them and this law is called Okun's rule of thumb. By this law according to the economics arm of Federal Reserve Bank of Saint Louis explain that this law tells us when unemployment rate is high or above the natural rate the country's GDP may be lost. It is a simple law that states a positive relation for employment and economic growth and a negative one between unemployment and economic growth.Okun presented two different versions of this law. The first one is :

\section{$\Delta \mathrm{Ut}=\mathrm{a}-\mathrm{b}^{*} \Delta \log \mathrm{GDPt}$}

this equation represent the ration of GDP and unemployment as 2:1 for the United States (Abel, 2008). It represents also the elasticity of the unemployment rate with the economic growth (Balakrishnan, 2010). $\Delta U$ t shows the change in the unemployment rate, $\triangle \log$ GDPt is the change in the GDP, is the level above the natural rate of the unemployment and $b$ is the Okun's coefficient (Neely, 2010) noted that this coefficient can change over time since the relation of unemployment to economic growth depends on technology, laws, preferences, demographics and social customs. Accept the equation it is important to say that the Okun's coefficient is by itself a good observer for the relationship of unemployment rate and the economic growth. However the instability of that over time, business cycles and regions was defined. This instability is related to late impact of unemployment rate to the changes in output that means there are other factors intervening in the relationship of them such as labor policies or uncertainty.

(Knotek, 2007) claims that if instability of it is considered this relationship becomes an important forecasting tool. After the financial crises of the 2008 the Okuns coefficient changed rapidly in some developed countries. After the behavior of that coefficient, scholars believed that are the technological, social and normative transformations of the past 30 years in the United States. (Neely, 2010) noted that industrialized countries have smaller Okun's coefficient because unemployment is simpler than changes in output since it is easy to fire workers. In Latin America because of the lack of data of the unemployment rate (Gonzalez, 2002) proposed use of the survey in order to find the data, he stated that it is better to use real wage instead of the unemployment rate because in case of the inflation real wages can push it dawn and avoiding lying off. The rule of Arthur Okuns had many critics but also people who support it. Ben Bernanke the Federal Reserve chairman summarizes that to reduce the unemployment the economy must growth at a level above its potential so to specify Okun's law says that if potential rate of gross domestic product growth is 2 percent the GDP must grow at 4 percent in a year to reach 1 percent reduction in unemployment.

Another interpretation of Okun's law was from the Kansas City fed that explains this law like the slowdowns of growth leads to the rising of unemployment. Some economics blogs supported that law and concluded that Okuns law is a useful guide for the monetary policy of the country if the unemployment rate is measured. Also the Keynesian economics emphasizes the government intervention in order to reduce the unemployment during recession. He said that government can increase demand for workers by expansionist monetary policy or financial stimuli. Keynes mentioned that unemployment is caused by investor who tries to receive money for themselves rather than to produce more products. Marxists had the same point 
of view with the Keynes but according to them the unemployment is inherent that means it is something that it is expected to happen. They think that unemployed workers does not bring profit but at the same time unemployment is profitable in the capitalist countries since contribute by lowering wages which are costs for the owners and the only way to eliminate unemployment is to abolish capitalism.

So the most important theory that is exactly for the relationship of the unemployment and the economic growth is the Okun's law that is mentioned before and it shows the negative relation that this paper supports by the empirical analysis also. This law it is important for the theoretical and empirical reasons. From theoretical part Okuns law is seen as macroeconomics building and from empirical point of view it is regarded as a hint for policymakers to calculate the cost of higher unemployment.

Some countries break the Okun Law that means in case of a fell in GDP the labor productivity increased. The countries that were abnormal, breaking this law were the US, Spain and the Ireland in the recession times. (Rowe, 2011) Okuns's law normally falls in recession, since the gross domestic product and the unemployment falls also. But in the US the ratio of GDP over unemployment didn't have a decline. In the years of 2008 and 2009 the GDP of US felt nearly 4 percent and the unemployment by 6 percent so the GDP over employment ratio increased by nearly 1 percent. (Rowe, 2011) Spain and Ireland were also breaking this law. Spain was like the US, this country had a decline in the GDP and in the unemployment but during this time the productivity of Spain increased by 6 percent. Ireland is also a special case where in the recession the GDP declined the employment declined also but the productivity of it increased to the same level it was before recession. These countries broke the Okuns law.

In the period of recession and the countries had a decline in their gross domestic product mostly in 2008 and 2009 then in 2011 there is a positive increase of the GDP of these countries. In the Ireland the GDP felt much than the other countries. Since in the recession there is a decline in the output also the consumption falls, drops in the international trade and many other effects.

Also the unemployment in the developed countries being part of the G8,in the period of the recession and it declines . So the unemployment increased. Okuns law it is not a theoretical view but an empirical one. Okuns law in difference with the Keynesian and monetarist theory that explains the recession as a cause of the fall of aggregate demand and the increase of the productivity when unemployment falls but the Okuns law states that the productivity falls.

Okuns law predicts that decline of economic growth coincide with increasing of the unemployment. But this is not always the case. Firstly Okuns law is not a tight relationship, because many growth slowdowns haven't lead to a rise in the unemployment and this varies from periods of time and from the business cycles. Anyway Okuns law can be a useful forecasting tool.

The relationship of the unemployment and the economic growth for the OECD countries changes from countries to countries and is not stable across time, but he concluded the impact of the economic growth in the unemployment. (Lee, 2000). The Okuns coefficient of the some OECD countries showed that in 1990 the employment growth was higher than in the other previous years (Baker and Schmitt, 1999).Many studies found the relation of the economic growth and the unemployment rate is useful the rule of thumb in the macroeconomics. The (IMF, 2010) stressed as important the fact that to explain the changes of Okuns coefficient from the different countries or times the institutions and policies are needed.

Mentioning the fact of the impact of the crises, (Fallon and Lucas, 2002) argued that the financial crises of the 1990 effected slightly the employment since this crises resulted only in the cuts of real wages. In contrast (Hall, 2010) said that in the period of crises the employment situation doesn't change since there is a poor bargaining ability of the people working.

\section{General View of Unemployment Rate in Albania}

After the communist regime Albania achieved an economical growth but still the poverty remains high. Since it is a poor country the high level of unemployment exists so it is important to discuss about this topic.

Unemployment still remains a problem in the Albanian economy. It refers to the labor force that is not working but available for or seeking employment. This group consists of students, the invalids and the ones performing military service also the persons that are not currently looking for a job. The working age population includes people from 16 years old to 65 years old for men and 60 for women.

Our country suffers from the phenomenon of the unemployment. As we see in the Figure 1 the lowest rate of unemployment during last ten years have been in 2009 about 12,5 percent and the highest rate of unemployment is 17 percent in 2002and 
2003.From this years the unemployment have been reducing but anyway the rate of unemployment for the Albania remains high.

Figure1: Unemployment rate in Albania

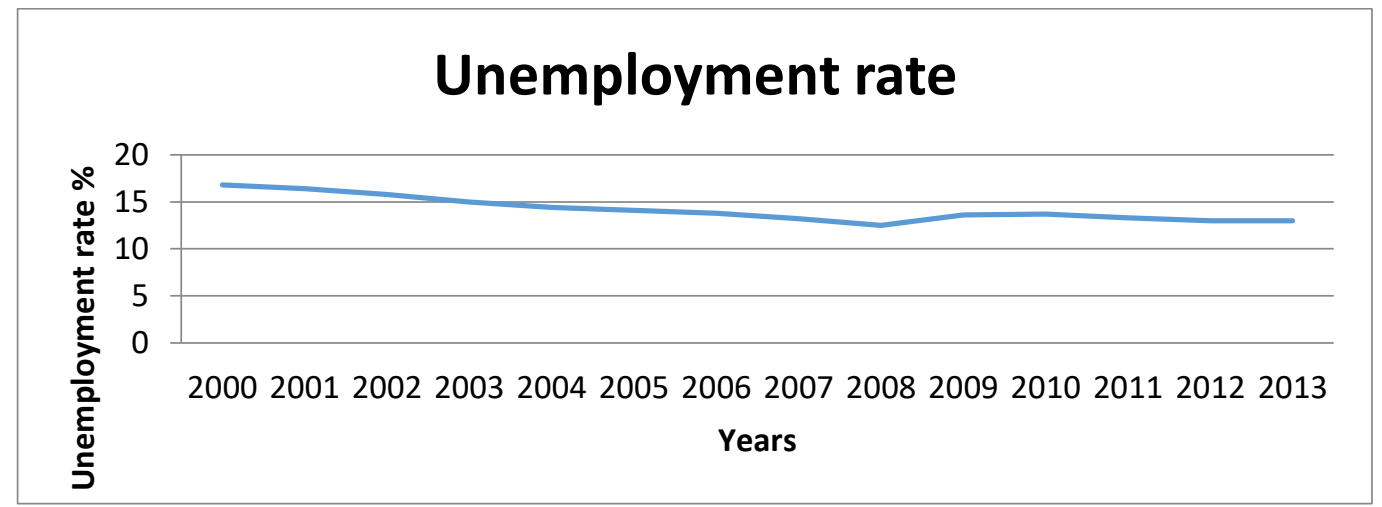

Source: INSTAT

According to the Central Intelligence Agency $(\mathrm{CIA})$ the unemployment rate of the Albania is not the real rate because of the main reason that is informality that means the number of the people currently working and not declared as employer. Also are some unemployed that do not declare themselves as unemployed. The other reason is that rural areas which are the poorest zones of the country are supposed with full employment since it has no one declared as unemployed. According to the CIA 58 percent of the labor force is concentrated in the agriculture, 27 percent in the service sector and only 15 percent in the industry. So a large labor force in the agriculture provides the 21.7 percent of GDP and zero unemployment making the unemployment rate no to be the real one.

Figure 2: Unemployment rate in Europe

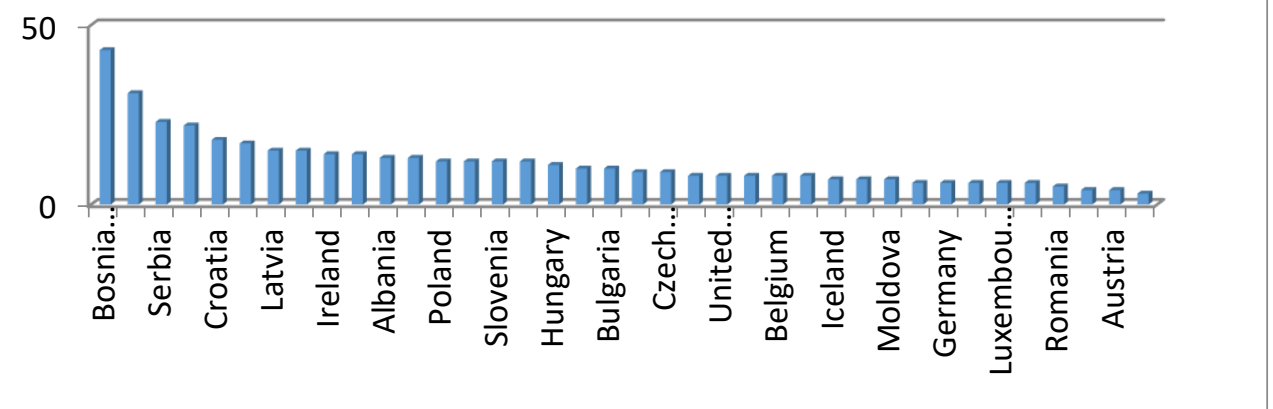

\section{Source :World Bank}

Now we will compare the unemployment rate of the Albania for the year 2011 with the unemployment rate of the other countries of the Europe some more developed and some less developed than Albania. Albania has experienced a transition for a long period so it is not a developed country. We see that the unemployment rate for the Albania in this year is approximately 13 percent, this rate is low comparing with the other European countries such AS Bosnia and Herzegovina with unemployment rate 42 percent also the level of the unemployment rate in Albania comparing with the other countries such as Serbia, Croatia or Latvia is lower .But is higher when comparing with developed countries such as United Kingdom, Bulgaria,Germany and the others. So even Albania has high level of unemployment there are some other countries of the region with higher level of the unemployment. 
Unemployment is a phenomenon that has many disadvantages for a country but advantages as well. The unemployment may avert the inflation; this is based on the Philips curve theory. Two macroeconomics goals are the full employment and the price stability, with the reduction of the unemployment labor market begins to recover. Companies find difficulty in finding qualified workers so because of the high competition they are going to increase the salary. Thus low unemployment leads to the increasing of the wages generates a rise in prices and causing the inflation. There exits an inverse relationship between the inflation and the unemployment the low unemployment lead to higher inflation. This relationship is called the Philips curve, data found by this economist analyzed that wages can be stable at5,5 percent, when unemployment rate is near zero the level of inflation is extremely high.

Figure3: Inflation rate of the Albania annually in percentage.

\section{Inflation rate}

10

0

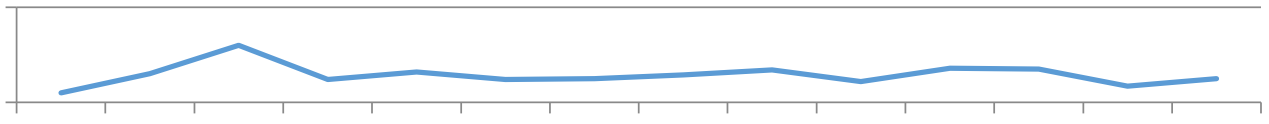

20002001200220032004200520062007200820092010201120122013

\section{Source: Index Mundi and Trading Economics}

To a zero level of inflation the unemployment is at its natural level and this can be seen in the year 1999.For low unemployment level prices increase and to a high level of unemployment prices tend to go down. That's the main benefit of the unemployment in a country. As we see in the figure 4 from 2000 to 2009 the level of inflation has changed. In 2000 the rate of inflation has been low and unemployment rate high, approximately 14 percent. In 2002 the inflation reached it maximum level and after that id drawn drastically and after that have been low changes. In 2009 the inflation rate was 3.4 percent regarding to the unemployment rate which was 12.5 percent. The government interaction is needed to keep in balance those two factors. It is important to interfere of the government to reduce the unemployment rate. Albanian government has taken some precautions to reduce the unemployment by opening new workplaces such as infrastructure. Also the government has raised the wages for many professions motivating in this manner the workers. The reforms in the fiscal system and the investment in the infrastructure and in the encouragement of the foreign investments are the important factors that have contributed in the economic growth and to the creation on new workplaces. As is mentioned before the unemployment is a process that happens in every country and it is inevitable. This phenomenon has negative effects such as social and economic effects and positive effect such as the prevention of the inflation.

Unemployment is caused by the level of wages the technological level and the job supply. Although Albania's currently economic growth has reduce poverty level the unemployment rate is still high and Albania remains one of the countries with the highest unemployment rate. Anyway this rate has been changing and in 2009 it was 12, 5 percent it is the lowest level that Albania has had in the last ten years matching with the inflation level 3.4 percent in this year.

A long period of unemployment may cause individual and social costs. Except the social negative effects that cause the unemployment results in loss of income and reduces the potential economy. The GDP becomes lower than it could be.sos all the whole economy and the society suffer from the unemployment. It has effect on the government expenditure, taxation and the level of government borrowing also. Tax revenue falls since the people aren't paying them because of not earning money themselves. This can result in an increase of the government deficit which than increases the risk that government will have.

Types of the unemployment:

- $\quad$ Frictional unemployment leaving a job and searching for another which may be better than first.

- Structural unemployment occurs due changes to demand and supply to work.

- Cyclical unemployment caused by a business cycle recession.

- Seasonal unemployment related to seasonal nature of the product or the service.

- Voluntary unemployment includes the people who don't want to work for different reasons.

- Hidden unemployment is unemployment that does not appear in the government statistics. 


\section{Economic growth}

Albania is a developing country but still remains one of the poorest countries in the region. Macroeconomic growth is 6 percent between 2004 and 2008 but in 2009 and 2011 declined by 3 percent and 0.5 percent in 2012. Inflation is low and stable. As we see in the GDP the main indicator of the economic growth the GDP has been high in the 1999 and it has many up and downs but with slow changes and in 2011 we see a decline of the GDP of the Albania which shows not a good situation for the economy of the Albania.

Figure4: GDP of the Albania.

\section{GDP}

ㅇํㅇ

18

20002001200220032004200520062007200820092010201120122013

Years

Source: World Bank

In 2000 the Albanian economy has been good and the living standard as well. But in the upcoming years except the 2003 that noticed a increased moment, the economic growth of Albania slowed down. In the period of 2006 till 2008 the economy was growing up and every aspects of it were positive, the poverty started to reduce, the unemployment to fall, the increase of the wages, no government debts, the investments increase also the export and the improvement of the quality of life. In 2008 the business cycle brought the recession for many countries for the Albanian also and the GDP declined, staying in negative trend till in nowadays. In the 2009 there was a slight increase but it doesn't have any important effect to get out the economy from the bad period of time. After 2009 the economy declines again and now it has the slowest rate that is 2 percent for the last decade.

However Albanian economy has improved with large steps in the last decade, many reforms that were important for the country like the ones in infrastructure, property law or business administration. The financial crises of the 2008 and 2009 spared largely the country; from 2009 till 2011 the GDP has stopped but remains positive.

The main challenges of the economy of the Albania are the fiscal and budgetary environment and the crises in the neighboring countries like in the Greece and Italy which are the main trading countries. In 2011 the GDP had reached approximately $\$ 13$ billion, the major contributions of GDP were services sector by 57.6 percent, agriculture by 20.3 percent, industry 11.3 percent and construction by 10.7 percent.

Remittances a significant catalyst for the economic growth meet declines over the last years after peaking in 2007.compared to 2009 in 2010 remittances fell by 16 percent and their share of GDP declined by 7.6 percent in 2010 .

Albania is taking into consideration the foreign investment regime and the government is working to improve the infrastructure and the business climate also. Foreign direct investments has increased over the last years and in 2010 reached \$ 1.1 billion. The government of Albania since in 2005 has invested $\$ 2$ billion in the countries road and it has pledged to invest in transportation infrastructure.

Albania is an import oriented country and the export is small and undiversified and the import remains large. Albania imports 41 percent of the GDP and 15 percent of GDP. In 2011 trade volume increased by approximately 16 percent, the exports by 22.6 percent and the imports by 13.6 percent. The trade deficit worsens by 9 percent year by year. (CIA World Factbook, 2011)

The main trading partners of the Albania are the EU countries. They provide 64.1 percent of the imports and receive 72.5 percent of the exports the largest share of the EU are represented by the Italy and Greece with 41.1 percent of imports and the 58.3 percent of the exports for the 2011.some other major trading countries are the Turkey, China and Germany.

Figure5: Comparison of annual GDP and unemployment rate of Albania from 2000 to 2013 


\section{GDP \& Unemployment rate}

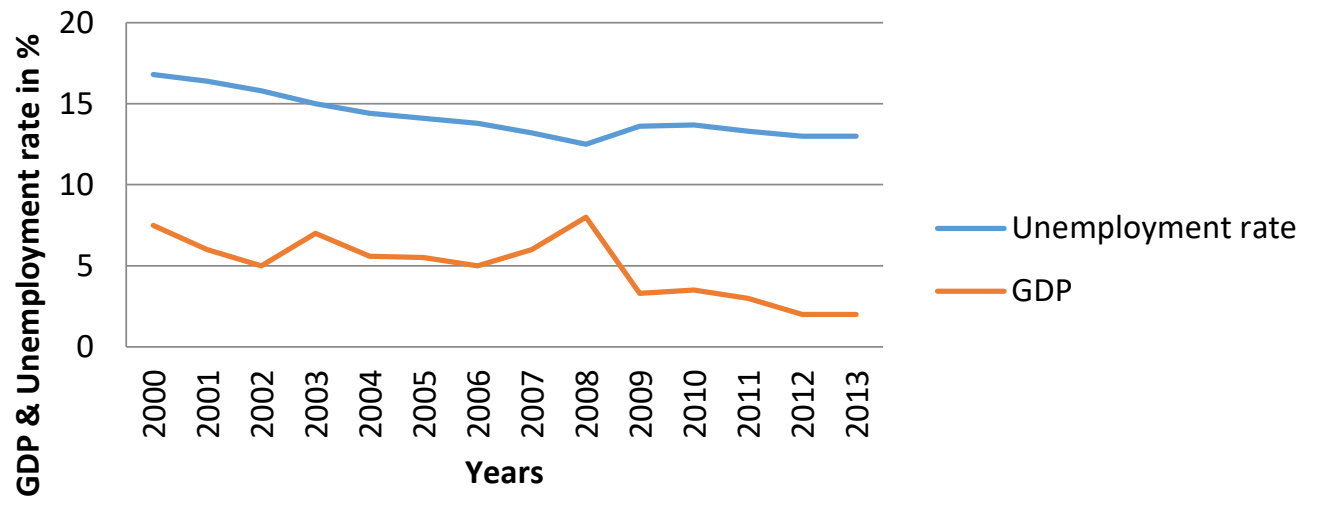

Source: Index Mundi and World Bank

This graph shows a not a regular relationship between the unemployment and the gross domestic product.

In the period 2000-2003 the economic growth of the Albania was low and the unemployment rate high. In the 2003 there is a slight increase in the economy which went up to 7 percent and a slight decrease in the unemployment rate.

In 2008 the gross domestic product reached the largest in Albania by 8 percent and the unemployment the lowest rate by 12.5 percent for the years 2000 to 2013.Then because of the international financial crises the economy of the Albania becomes poor and the GDP declines, affecting negatively the unemployment rate.

Based on this evidence it is difficult to conclude the link that exist between unemployment and the GDP in Albania.

Figure6 :GDP of Albania comparing to the other developing countries

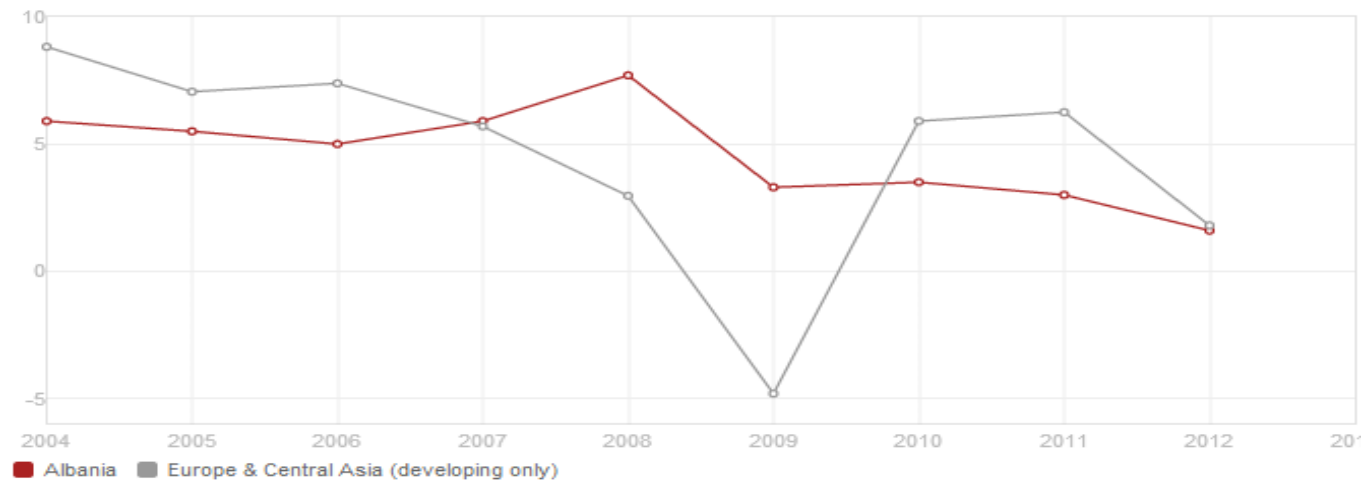

Source: World Bank

When comparison to the other developing country Albanian economy it is realized that has been lower than the other countries but again in a positive trend and only in 2008 because of the crises, the GDP of it felt immediately but it was higher than the economic growth of the other European and Asian countries which had a large decline in gross domestic product because of the recession which brought negative effect on the overall economy. From 2004 till in 2007 the annual average GDP has been approximately 6,5 percent and then the countries reached the same level in 2007 by 6 percent approximately. In 2007-2008 periods the Albanian economic growth went up to 8 percent. 
However in 2008 the growth of the economy slowed down. In this year Albania had the largest GDP by 8 percent than it started declining. In the years 2008 and 2009 the GDP of Albania was larger in comparison to the some developing countries being part of the Europe and Central Asia. But in 2009 these countries increased very much and reached a level to approximately 6 percent. After this period of time the GDP of all these countries had a declining trend and again reaching the same level to 2 percent the lowest that Albania has had after 2000.

\section{Methodology}

In this thesis is studied the relationship between unemployment and the economic growth for the Albania. This relationship is observed by Arthur Okun and called Okun's law. This law suggested two classes of it, the first one is first-difference model and the second is "gap" model. The first model gives the relation of these two variables by using the given formula:

$\frac{y_{t-} y_{t-1}}{y_{t-1}}=a+b\left(u_{t}-u_{t-1}\right)$.Where $a$ is the GDP growth and the $b$ is the Okun's coefficient. This model is used in this methodology. The regression analysis is a simple regression with only two variables where the GDP is dependent and the unemployment rate independent. According to the Okun's law the unemployment rate affect the GDP with the report 1:3 that means 1 percent decrease in unemployment the GDP increases by 3 percent. Does this rapport exist also for Albania? What is the impact of the GDP in unemployment? By using the estimated model we will find a detailed answer.

\section{V.IData}

This study uses annual data to examine the correlation between unemployment rate and the gross domestic product in Albania for the years 1992 till 2012. Yearly data on unemployment and gross domestic product are collected from the World Bank (WB). Since the first model of Okun's law is used the data are the changes in the unemployment rate and the changes in the GDP.

GDP real growth is the dependent variable while unemployment rate is taken as independent. These variables are analyzed in their level form. Economic growth is measured by the gross domestic product while the unemployment rate is measured by annual unemployment

rate.

Data used in the regression in order to study empirically the effect that variables have to each other, and to proof of the Okun's law functions for the Albanian economy also. This study has 21 observation for the unemployment rate and 21 for the GDP of the Albania.

Figure 7: Linear Regression

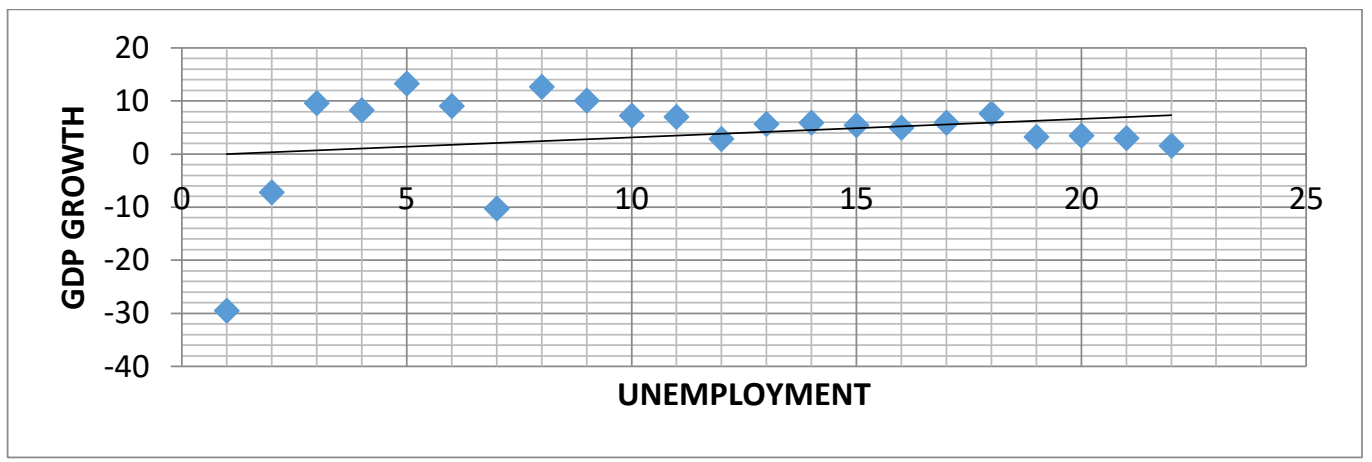

This scatter diagram illustrates the link between GDP growth and the unemployment rate in Albania over periods 1992 and 2012, from the figure is observed no clear systematic relationship between the variables.

In fact the dates of the GDP and unemployment show diverse relations in different years, where only in 2008 we can see a key negative link between GDP and the unemployment rate. From the year 1991 that this study takes into consideration the GDP started to increase and the unemployment had the same trend.

Since Albania was in transition the economy of it started to improve after 1990 but with low steps, this effected the employment but in negative sight so the employment decreases while GDP was increasing. This happens since there was 
no more a central economy, the private businesses started creating, and people were free in their choices but this had not good impact in employment.

The number of unemployed increased because of the new political environment that came and firing lots of employees of the administration, so they didn't have the opportunity to work immediately anywhere.

\section{V.II Regression Analysis}

Here we test the first difference model of the Okun's law. By using the two variables unemployment and the GDP the model will be estimated and the result that shows the affect of them to each other will be found.

Table 1: Reggression Analysis

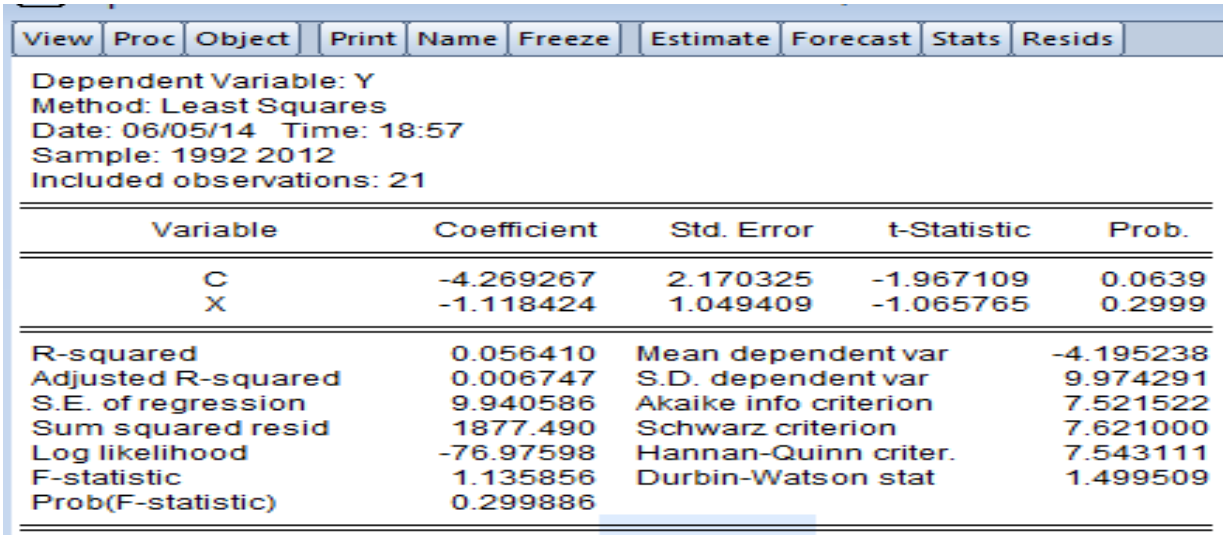

The Regression equation is:

$\mathrm{Y}=B_{0}+B_{1} \mathrm{X}+\mathrm{u}$

Where:

Y- is the depended variable, which is being predicted or explained, in this case the differences in real GDP.

$\boldsymbol{B}_{\mathbf{0}}$ - is the expected intercept parameter, equals the value of $Y$ when the value of $\mathrm{x}=0$.

$\boldsymbol{B}_{\mathbf{1}}$ - is the expected slope, how much $\mathrm{Y}$ changes for each one-unit change in $\mathrm{x}$.

$\mathbf{x}$ - is the independent or explanatory variable, in this case the differences in unemployment rate.

$\mathrm{u}$ - is the error term; the error in predicting the value of $\mathrm{Y}$, given the value of $\mathrm{X}$ (it is not displayed in most regression equations).

To examine the relationship between the GDP and the unemployment rate the study specified the simple linear model:

$$
Y=-4.26-1.11 x
$$

The above equation shows that one percent point decline in the unemployment rate would produce 1.11 percent growth in the GDP. If the unemployment rate remains constant the GDP decline by 4.26 percent this happens since implying the unemployment is not the only factor affecting the economic growth.

The Okun's coefficient varies from countries and from period of time. In 2012 the Okun's coefficient in industrial countries of Europe was -4, in Japan -8 in Greece -4.2, in Macedonia - 3.8 and so on.

For the statistical significance, t-statistics is going to be studied. t- Statistics $=-1.96$ it means that the unemployment rate is statistically significant, furthermore, means that the independent variable or $X$, should be kept in the regression equation, since it has a statistically considerable relationship with the dependent variable that is unemployment rate.

When $R^{2}$ is studied, that shows how much of the dependent variable is explained by the change of the independent variable. $R^{2}=0.056$ that means approximately 6 percent for the change of GDP can be explained by a change in unemployment rate. There are many factors that affect the GDP of the Albania like the foreign direct investments, 
population growth or technological innovations. In this analyze it is shown that economic growth and unemployment rate have a weak relation with each other.

This relation says that 5.6 percent of the economic growth is explained by the unemployment rate and the other 94.4 percent by the other factors. Table shows that this is a weak correlation. Although this is contrary to a priori expectation, the result is not surprising since the economy of Albania has experienced a decrease in the overall economy that's why the implication is that the GDP is insensitive from the unemployment rate.

We cannot have an exact correlation between this two important variables since the data of the Albania are not reliable and do not give us the opportunity to do right calculations.

\section{Vl. Conclusions and Recommendations}

This study examines the relationship between the differences in the annual unemployment rate and the differences in the annual GDP of Albania for the period 1992 and 2012.the Okun's law states that one percent decrease of in unemployment rate the GDP increase by 3 percent, but this law varies from country and period of time. Okun's law holds for the economy of Albania over the period 1992-2012. The estimation results found that one percent reduce in the unemployment rate the GDP increases by 1.11 percent. The Okun's coefficient for Albania is sufficiently small since there is no competent labor and supply.

The data and the study do not show a specific and stable rapport since from years to year we can see different link between the GDP and the unemployment. This happens because of the situation in Albania, being a transition economy ,the crises that started at 2008 and still it continues and also the change in the government that affected the economy of Albania overall.

The economic growth in Albania it is unsatisfied even there have been 20 years of democratization. There is high unemployment and it is urgently needed development of employment politics. The economic growth must be oriented toward the sectors that can create more jobs, at the same time a balanced distribution of public investment in the country. Also a greater wage and the flexibility of labor market is important to increase the Okun's coefficient for Albania and the support of economic growth.

\section{References}

[1] Francesco Bartolucci,Misbah T. Choudhry, Enrico Marelli,Marcello Signorelli. (n.d.). Financial Crises and Unemployment: Beyond the Okun's Law.

[2] (2011, April). Retrieved from CIA World Factbook.

[3] Abel. (2008). Macroeconomics (sixth edition).

[4] AMASSOMA, Ditimi, NWOSA, Philip Ifeakachukwu. (2013). THE IMPACT OF UNEMPLOYMENT RATE ON PRODUCTIVITY GROWTH IN NIGERIA.

[5] Amezaga, M. J. (2012). UNEMPLOYMENT AND ECONOMIC GROWTH IN PERU.

[6] Arshad, Z. (2009). The Validity of Okun's Law in the Swedish Economy.

[7] Baker and Schmitt. (1999). The Macroeconomic Roots of High Unemployment: thelmpact of Foreign Growth.

[8] Balakrishnan. (2010). Unemployment dynamics during recessions and recoveries:Okun's Law and beyond.

[9] Dritan Shoraj,Fejzi Kolaneci. (n.d.). Test of Okun's Law in Albania during the period 1995-2010.

[10] Fallon and Lucas. (2002). "The Impact of Financial Crises on Labor Markets, Household Income and Poverty :A Review of Evidence.

[11] Fuhrmann, R. C. (2012). Okun's Law: Economic Growth And Unemployment.

[12] Gonzalez. (2002). Labor Market Flexibility in Thirteen Latin American Countries and the United States.

[13] Hall. (2010). Why Does the Economy Fall to Pieces after a Financial Crisis?

[14] IMF. (2010). "Unemployment Dynamics During Recessions and Recoveries: Okun's Law and Beyond.

[15] Knotek. (2007). How Useful is Okun's Law? 
[16] Kota. (2007). Determinats of Economic Growth in Albania.

[17] Lee, J. (2000). "The Robustness of Okun's law evidence from OECD countries".

[18] Levine, L. (2012). Economic Growth and the Unemployment Rate.

[19] Mahmoud A. Al-Habees,Mohammed Abu Rumman. (2012). The Relationship Between Unemployment and Economic Growth in Jordan and Some Arab Countries.

[20] Neely. (2010). Okun's Law: Output and Unemployment. Rowe, N. (2011). Worthwhile Canadian Initiative.

\section{Appendix}

Appendix A: Table of data used in the regression analysis

\begin{tabular}{|l|l|l|l|}
\hline 1992 & -36.7 & 3.9 \\
\hline 1993 & 2.4 & -0.41 & -0.5 \\
\hline 1994 & -1.3 & -2.29 \\
\hline 1995 & 5 & 1.5 \\
\hline 1996 & -4.2 & -1.71 \\
\hline 1997 & -19.3 & 0.41 \\
\hline 1998 & -22.9 & -6.2 \\
\hline 1999 & -2.6 & -0.31 \\
\hline 2000 & -2.8 & -0.5 \\
\hline 2001 & -0.3 & -0.19 \\
\hline 2002 & -4.1 & -0.11 \\
\hline 2003 & 2.8 & 1.11 \\
\hline 2004 & 0.2 & -0.5 \\
\hline 2005 & -0.4 & 0.8 \\
\hline 2006 & -0.5 & 0.39 \\
\hline 2007 & 0.9 & 0.11 \\
\hline 2008 & 1.8 & 0.39 \\
\hline 2009 & -4.4 & -1.39 \\
\hline 2010 & 0.2 & -0.39 \\
\hline 2011 & -0.5 & \\
\hline 2012 & -1.4 & & \\
\hline $5040:$ & & & \\
\hline
\end{tabular}

Source:World Bank 